\title{
Effect of Compacting Temperature on Marshall Properties in 80/100 Grade and PMB Bituminous Concrete Mixes
}

\author{
Dr. Dwaitha Jagadish ${ }^{1}$, M.Durga ${ }^{2}$ \\ ${ }^{1}$ Assistant Professor, Civil Engineering, Jain (Deemed to be) University, Bangalore, Karnataka \\ ${ }^{2}$ Assistant Professor, Civil Engineering Arba Minch University, Ethiopia
}

\begin{abstract}
As we all know Pavement is a structure constructed to provide safe, durable and good riding surface with minimum maintenance. Hence it is very much important to make the pavement functionally and structurally sound throughout its life. The ability to characterize asphalt pavement materials in terms of their fundamental properties is becoming increasingly more important.

The performance of the bituminous pavements mainly depends upon the material property, gradation, type of filler material, binder, mixing and compaction temperature. Therefore, it is essential to study the effect of temperature both during mixing and compacting the material to produce a given mix. The variation in the temperature during mixing and compacting will result in variation in bituminous mix fundamental properties.

This paper will show how the effect of compaction temperature changes in Marshall properties of different Bituminous Concrete mixes such as 80/100 Grade and PMB (Polymer Modified Binder) and also variation in Marshall Properties in soaked condition will show how the pavement react when it comes in contact with water during rain.
\end{abstract}

Key words: Compaction temperature, PMB, 80/100, stripping, Soaking Index, Marshall Properties, Marshall Stability

\subsection{General}

\section{INTRODUCTION}

The design of bituminous mix by Marshall Method involves the Grading of the aggregates and bitumen to produce a mix that will have the adequate qualities and properties. The purpose is to develop a design, by trial means, which will contain optimum amount of bitumen, having adequate voids, satisfactory flow properties and possess a proper combination of stability, durability and flexibility, based on the climatic condition, traffic density and loads that it will carry.

Bituminous mix consists of a combination of aggregate uniformly mixed and coated with bitumen binder. Term "hot mix" comes from mixing of dry aggregate with bitumen heated for proper mixing temperature to attain workability of mix with desired temperature. Polymer modified bitumen is emerging as one of the important construction materials for flexible pavement. Choice of polymers varies from virgin polymer to waste rubber. Generally, the polymers are either blended or dispersed with bitumen and the mix is used as the modified binder.

Once the Aggregate and Asphalt are combined in the mixing plant, the mix will be transported to site and spread with paving machine in loosely compacted layer to uniform, smooth surface. Then the mix will be compacted by heavy roller to produce smooth and well consolidated course.

Compaction is one of major issue in bituminous mix and important criteria in process to produce good quality of hot mix asphalt. There are various instances where surface layer has failed due to carelessness in maintaining proper temperature during mixing and compaction.

Compacting bitumen at too high temperature also may result in hairline cracks and mix displacement and if the bitumen is compacted at too low a temperature, there is a risk that the bonds between the aggregate and the binder will break up, or that the aggregate will be crushed.

Determining the compacting temperature will help to controls bitumen viscosity which affects its ability to coat and provide adequate lubrication for aggregates to slides with each other and pack into dense mass during compaction.

\subsection{Objectives of the Present Study}

- To determine the effect of compaction temperature on the properties of a compacted bituminous concrete surface course mix.

- To establish the relationships between the fundamental mix properties i.e, Marshall Stability, Flow, Unit Weight, Voids Filled with Bitumen (VFB), Voids ratio (Vv) and compacting temperature.

- To study the effect of compacting temperature on the soaking condition in the laboratory for BC mix. 


\title{
International Advanced Research Journal in Science, Engineering and Technology
}

\author{
Vol. 8, Issue 8, August 2021
}

DOI: $10.17148 /$ IARJSET.2021.8877

\subsection{Scope of the Present Study}

- $\quad$ Preparation of conventional Marshall Stability test compaction specimens of BC mix using different binders such as $80 / 100$ and $\mathrm{PMB}$ for various compacting temperatures of $100^{\circ} \mathrm{C}, 120^{\circ} \mathrm{C}, 140^{\circ} \mathrm{C}, 160^{\circ} \mathrm{C}$.

- $\quad$ To determine the mix properties Vv, VFB, Unit Weight for the above specimens.

- $\quad$ To conduct Marshall Stability of Unsoaked specimens for the prepared specimens.

\subsection{General}

\section{LITERATURE REVIEW}

There are various instances where surface layer has failed due to carelessness in maintaining proper temperature during mixing and compaction. Bitumen is a thermo plastic material. It means that the consistency of the material changes with change in temperature. Bitumen softens whenever it is heated and becomes more viscous (i.e. high resistance to flow) when cooled. Consistency of bitumen binders generally accepted in India is based on standard tests namely, penetration, ductility and softening point. The physical properties of bitumen mixtures are very much influenced by the rheological properties of the binder. The requirement of bituminous mixtures is to have high compressive strength to resist the deformation caused by the traffic load. It is also desirable for the mixture to have an adequate tensile strength to resist wheel friction and tension caused by contraction. The bituminous surface should also have certain elastic property to prevent developments of cracks due to deformation. In addition to have sufficient stability to prevent crushing, the bituminous pavements should be sufficiently dense to make it water proof and durable to preserve these qualities. The above properties of bituminous mixtures can be achieved by proper selection of ingredients of the mixture. Even after the proper selection of materials, specifications and proper mix design, the properties of bituminous mixes are governed by other factors also. These factors include time and temperature of heating, Mixing, type of compaction, curing etc. ${ }^{[5]}$

\subsection{History of Research}

Hadley (1970) et al has conducted an extensive laboratory study to find the effect of seven factors on the tensile properties of asphalt material. The result of the studies showed that compaction temperature along with asphalt content, grade of asphalt, and aggregate gradation has significant cause to tensile strength. In this study also the entire result was affected by the compaction temperature and produced strong interaction with other variables. ${ }^{[12]}$

Hadley (1978) conducted second laboratory test and founded that reclaiming agent and compaction temperature has certain effect to the significant increase in tensile strength, static and resilient modulus of elasticity. However, as the amount of reclaiming agent increase, the effect of compaction temperature was more important. The viscosity effect seems to be minimal since all samples were heated and mixed at the same temperature of $135^{\circ} \mathrm{C}$. This experiment was conducted using recycled asphalt mixtures.

\subsection{Effect of Compaction Temperature}

The effect of compaction temperature is evaluated during quality control/quality assurance testing. Inaccurate control of compaction temperature could very well occur. It has always been assumed that the compacted density of bituminous concrete is very dependent upon the temperature. Studies have shown that, the percentage of air voids achieved by the Marshall hammer decreased from approximately 10.3 to 7.1.Therefore, the compaction temperature of the prepared mixes was varied to determine whether or not poor control would significantly increase the variability of volumetric properties. The effects of compaction temperature can be subdivided with respect to density and engineering properties. In procedure of pavement construction the compaction is done when temperature reaches $110^{\circ} \mathrm{C}$ and in laboratory bituminous mix normally compacted when temperature reaches $145^{\circ} \mathrm{C}$.

\subsection{Materials used in the study}

\section{PRESENT INVESTIGATION}

\section{A. Aggregates}

Granite aggregates available in the quarry near Bangalore was selected for mix design. Aggregate fraction retained on IS sieve $4.75 \mathrm{~mm}$ was used as coarse aggregate. Aggregates retained on IS sieve $.075 \mathrm{~mm}$ was used as fine aggregate.

Table 3.1 Specific gravity of aggregates used in current study

\begin{tabular}{|c|c|c|}
\hline SI No & Type of Aggregates & Specific Gravity \\
\hline $\mathbf{1}$ & Coarse aggregate, $20 \mathrm{~mm}$ & 2.69 \\
\hline $\mathbf{2}$ & Coarse aggregate, $12 \mathrm{~mm}$ & 2.68 \\
\hline $\mathbf{3}$ & Coarse aggregate, $6 \mathrm{~mm}$ & 2.67 \\
\hline $\mathbf{4}$ & Fine aggregates & 2.72 \\
\hline
\end{tabular}


International Advanced Research Journal in Science, Engineering and Technology

Vol. 8, Issue 8, August 2021

DOI: $10.17148 /$ IARJSET.2021.8877

Table 3.2 Properties of aggregates used in present study

\begin{tabular}{|c|l|l|l|}
\hline Sl no & Property & Values & $\begin{array}{l}\text { MORT\&H } \\
\text { Specification }\end{array}$ \\
\hline 1 & Los Angels Abrasion value & $26.80 \%$ & MAX 40\% \\
\hline 2 & Aggregate Crushing value & $34.66 \%$ & MAX 45\% \\
\hline 3 & Aggregate Impact value & $25.68 \%$ & MAX 30\% \\
\hline 4 & Flakiness Index & $9.50 \%$ & MAX 15\% \\
\hline 5 & Elongation Index & $17.50 \%$ & -- \\
\hline 6 & Combined Elongation and Flakiness Indices & $21 \%$ & MAX 30\% \\
\hline 7 & Angularity Number & 8 & 0 TO 11 \\
\hline
\end{tabular}

B. Bitumen (Tests on Binders)

Bitumen of grade 80/100 and PMB are used for this study and the physical properties of the bitumen were tested and the results are given in the Table 3.3

Table 3.3 Properties of Bitumen used for study

\begin{tabular}{|r|l|c|c|l|}
\hline \multirow{2}{*}{$\begin{array}{l}\text { Sl } \\
\text { no }\end{array}$} & \multicolumn{1}{|c|}{ Property } & \multicolumn{2}{|c|}{ Grade } & \multirow{2}{*}{ Test Method } \\
\cline { 3 - 4 } & & $\mathbf{8 0 / 1 0 0}$ & PMB & \\
\hline 1 & Penetration $(\mathrm{mm})$ & 85 & 70 & IS: $1203-1978$ \\
\hline 2 & Softening Point, ${ }^{\circ} \mathrm{C}$ & 47 & 55 & IS: $1205-1978$ \\
\hline 3 & Ductility at $27^{\circ} \mathrm{C}, \mathrm{cm}$ & 85 & 60 & IS: $1208-1979$ \\
\hline 4 & Specific Gravity & 1.2 & 1.2 & IS: $1202-1980$ \\
\hline 5 & Flash and Fire Point, ${ }^{\circ} \mathrm{C}$ & 265 & 220 & IS: $1209-1981$ \\
\hline
\end{tabular}

\subsection{Aggregate Gradation Obtained for mix}

The different sizes of aggregates i.e. $20 \mathrm{~mm}, 12 \mathrm{~mm}$ and $6 \mathrm{~mm}$ are selected from the heap and the sieve analysis is done to obtain the individual gradation of these aggregates. Then by Trial and Error method, the desired gradation for BC (Bituminous Concrete) mix is obtained to match the midpoint gradation and is shown in the Table 3.4

Table 3.4 Aggregate Gradation for Marshall Specimens for BC Mix (As per MoRT\&H Specification) and Obtained Gradation

\begin{tabular}{|c|c|c|c|}
\hline IS Sieve (mm) & \% passing (specified) & $\begin{array}{c}\text { \% passing (Mid- } \\
\text { Limit) }\end{array}$ & \% passing (obtained) \\
\hline 26.5 & 100 & 100 & 100.00 \\
\hline 19 & $90-100$ & 95 & 90.16 \\
\hline 9.5 & $56-80$ & 68 & 65.00 \\
\hline 4.75 & $35-65$ & 50.5 & 50.29 \\
\hline 2.36 & $23-49$ & 36 & 31.92 \\
\hline 0.3 & $5-19$ & 12 & 13.02 \\
\hline 0.075 & $2-8$ & 5 & 4.62 \\
\hline
\end{tabular}


International Advanced Research Journal in Science, Engineering and Technology

Vol. 8, Issue 8, August 2021

DOI: 10.17148/IARJSET.2021.8877

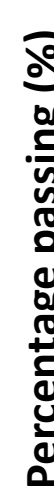

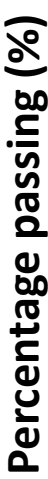

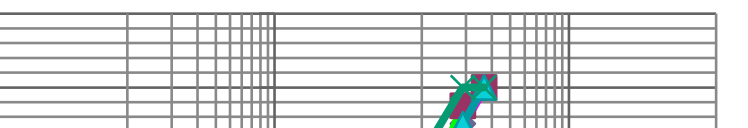

120.00

$100.00 \rightarrow$ Observed values

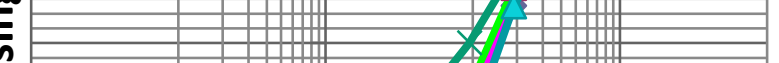

\begin{tabular}{|l||l||l|}
\hline \hline \\
\hline 2
\end{tabular}

ए

ע

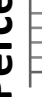

0.01

1

100
80.00

$60.00 \rightarrow-M i d d l e$ Limits

40.00

20.00

0.00

\section{Sieve size in $(\mathrm{mm})$}

Fig 3.1: Obtained Gradation

\subsection{Marshal Stability Test Conducted on Bituminous mix}

The properties like stability and bulk density of any bituminous mix are mainly dependent on gradation of aggregate, binder content, the type of compaction, method adopted for compaction, and the temperature during compaction.

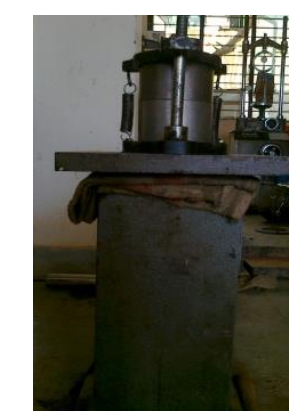

Manual Compaction

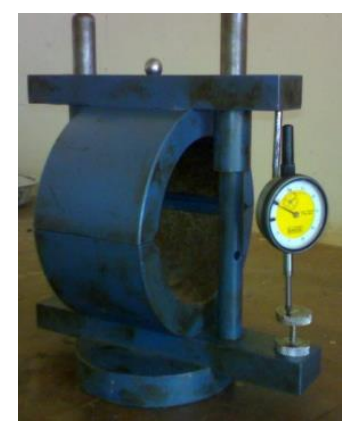

Breaking Head

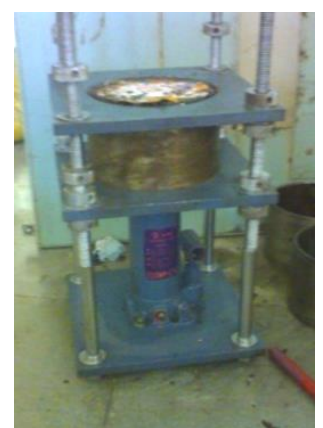

Specimen Extractor

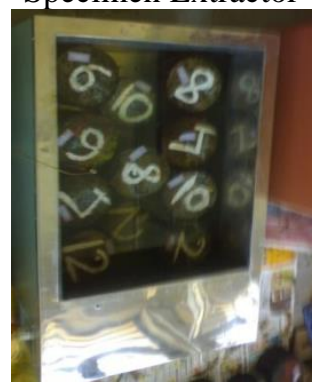

Water Bath 
DOI: 10.17148/IARJSET.2021.8877

Fig 3.2: Apparatus for Marshal Stability Test
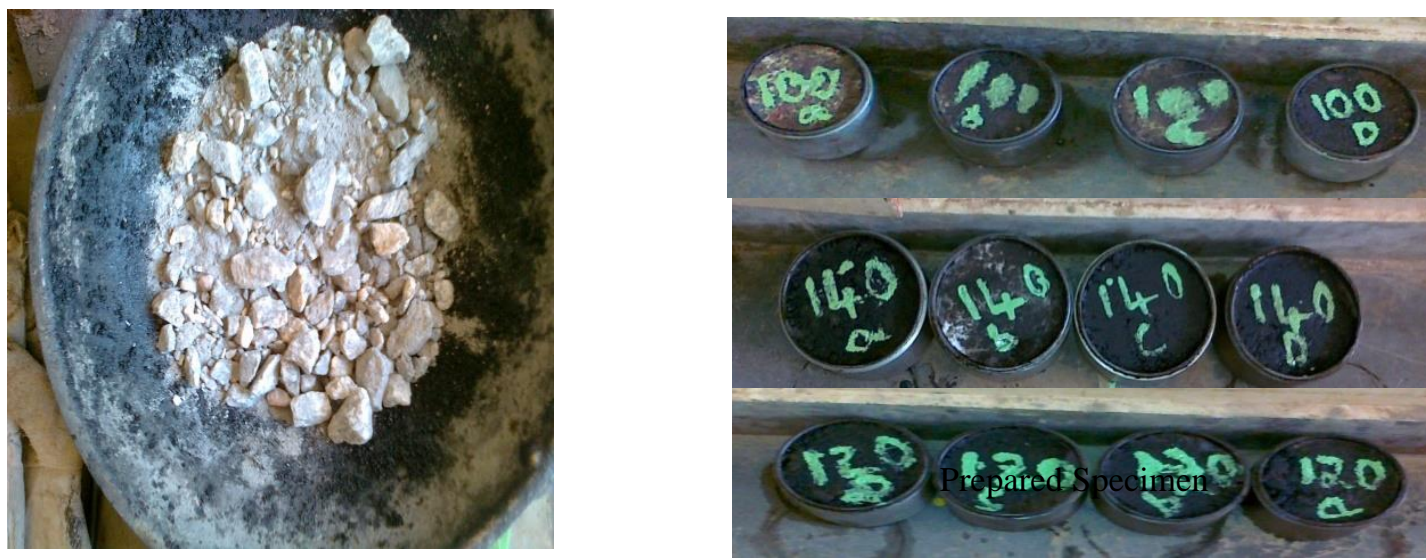

Aggregate Mix
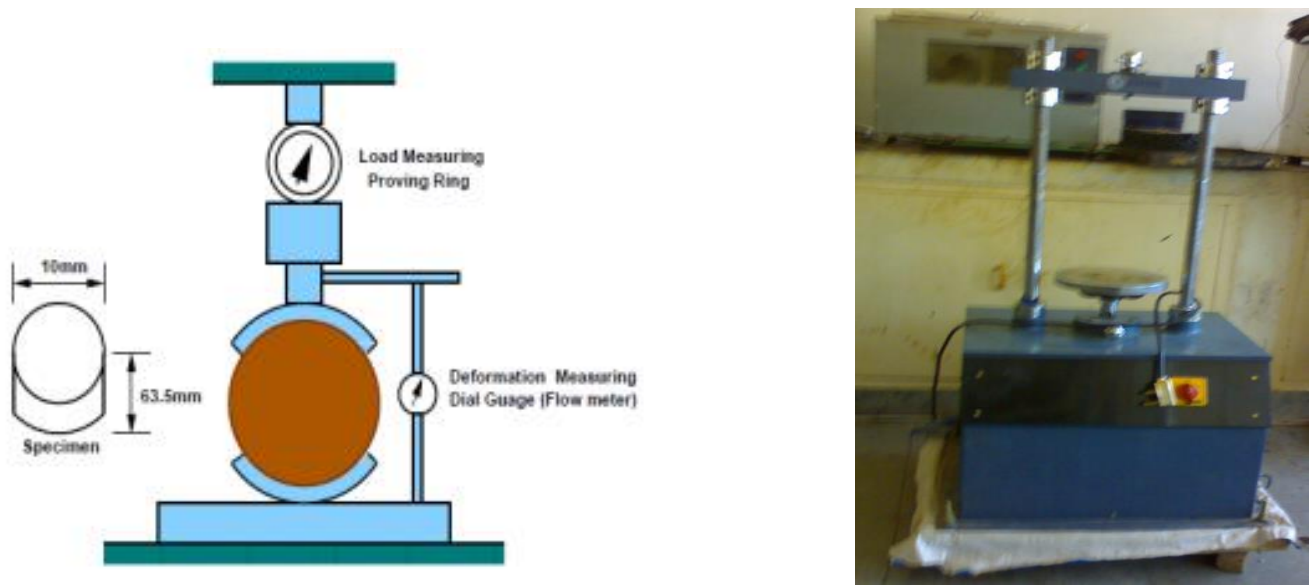

Marshall Stability Testing Machine

Fig 3.3: Preparation of the specimen for Marshall Stability Test

As per MoRT\&H, Compaction temperature for different grade of Bitumen is $100^{\circ} \mathrm{C}$ to $120^{\circ} \mathrm{C}$ and as per IRC SP-53-2002 Compaction temperature for Polymer Bitumen $115^{\circ} \mathrm{C}$ to $135^{\circ} \mathrm{C}$. Therefore for the present investigation, $\mathrm{BC}$ mix using 80/100 grade and PMB-70 at various compaction temperatures were tried to investigate the effect on Marshall Properties of the mix.

As per the above standards, the minimum compaction temperature for $80 / 100$ and $\mathrm{PMB}$ mix is $100^{\circ} \mathrm{C}$ and $115^{\circ} \mathrm{C}$. For the present study, the compaction temperature were varied from $100^{\circ} \mathrm{C}$ to $160^{\circ} \mathrm{C}$ with an interval of $20^{\circ} \mathrm{C}$ i.e. $100^{\circ} \mathrm{C}, 120^{\circ} \mathrm{C}$, $140^{\circ} \mathrm{C} \& 160^{\circ} \mathrm{C}$.

\subsection{Determination of OBC (Optimum Binder Content)}

\section{ANALYSIS OF DATA OBTAINED}

Marshall Stability specimens were prepared with $80 / 100$ plain bitumen by, varying the binder content from $4.2 \%$ to $7.2 \%$ by an increment of $0.5 \%$. Three specimens were prepared for each binder content.

Marshall Stability test was conducted and properties like stability, flow, bulk density, volume of voids and voids filled with bitumen were found for 80/100 plain bitumen. Using these properties, optimum binder content is calculated corresponding for maximum stability, maximum bulk density and $4 \%$ volume of voids.

Table 4.1 Marshall Stability properties for various bitumen content

\begin{tabular}{|c|c|c|c|c|c|c|}
\hline $\begin{array}{l}\text { Bitumen } \\
\%\end{array}$ & $\begin{array}{l}\text { Marshall } \\
\text { Stability,kg }\end{array}$ & $\begin{array}{l}\text { Flow, } \\
\mathrm{mm}\end{array}$ & $\begin{array}{l}\text { Bulk density, } \\
\mathrm{g} / \mathrm{cc}\end{array}$ & $\begin{array}{l}\text { Voids } \\
\text { ratio\% }\end{array}$ & $\begin{array}{l}\text { Voids in Mineral } \\
\text { Aggregate, } \%\end{array}$ & $\begin{array}{l}\text { Voids filled with } \\
\text { Bitumen, } \%\end{array}$ \\
\hline 4.20 & 1250 & 2.60 & 2.217 & 13.32 & 22.67 & 40.26 \\
\hline 4.70 & 1350 & 3.40 & 2.286 & 9.31 & 19.85 & 53.08 \\
\hline
\end{tabular}


International Advanced Research Journal in Science, Engineering and Technology

Vol. 8, Issue 8, August 2021

DOI: $10.17148 /$ IARJSET.2021.8877

\begin{tabular}{|l|l|l|l|l|l|l|}
\hline 5.20 & 1450 & 3.75 & 2.324 & 7.60 & 18.66 & 63.49 \\
\hline 5.70 & 1325 & 4.32 & 2.310 & 7.01 & 19.92 & 64.80 \\
\hline 6.20 & 1310 & 5.40 & 2.302 & 6.91 & 20.90 & 66.95 \\
\hline 6.70 & 1260 & 5.80 & 2.351 & 3.40 & 18.84 & 81.96 \\
\hline 7.20 & 1190 & 6.20 & 2.352 & 2.87 & 19.47 & 85.24 \\
\hline
\end{tabular}

Table 4.2 Results obtained from graphs:

\begin{tabular}{|l|l|l|l|l|}
\hline 1 & Maximum Stability, Kg & 1450 & At bitumen content $5.2 \%$ & \\
\cline { 1 - 3 } 2 & Maximum Bulk density, g/cc & 2.324 & At bitumen content $5.2 \%$ & Average $=\mathbf{5 . 2 \%}$ \\
\cline { 1 - 3 } 3 & Percent air voids & $4 \%$ & At bitumen content $5.2 \%$ & \\
\hline
\end{tabular}
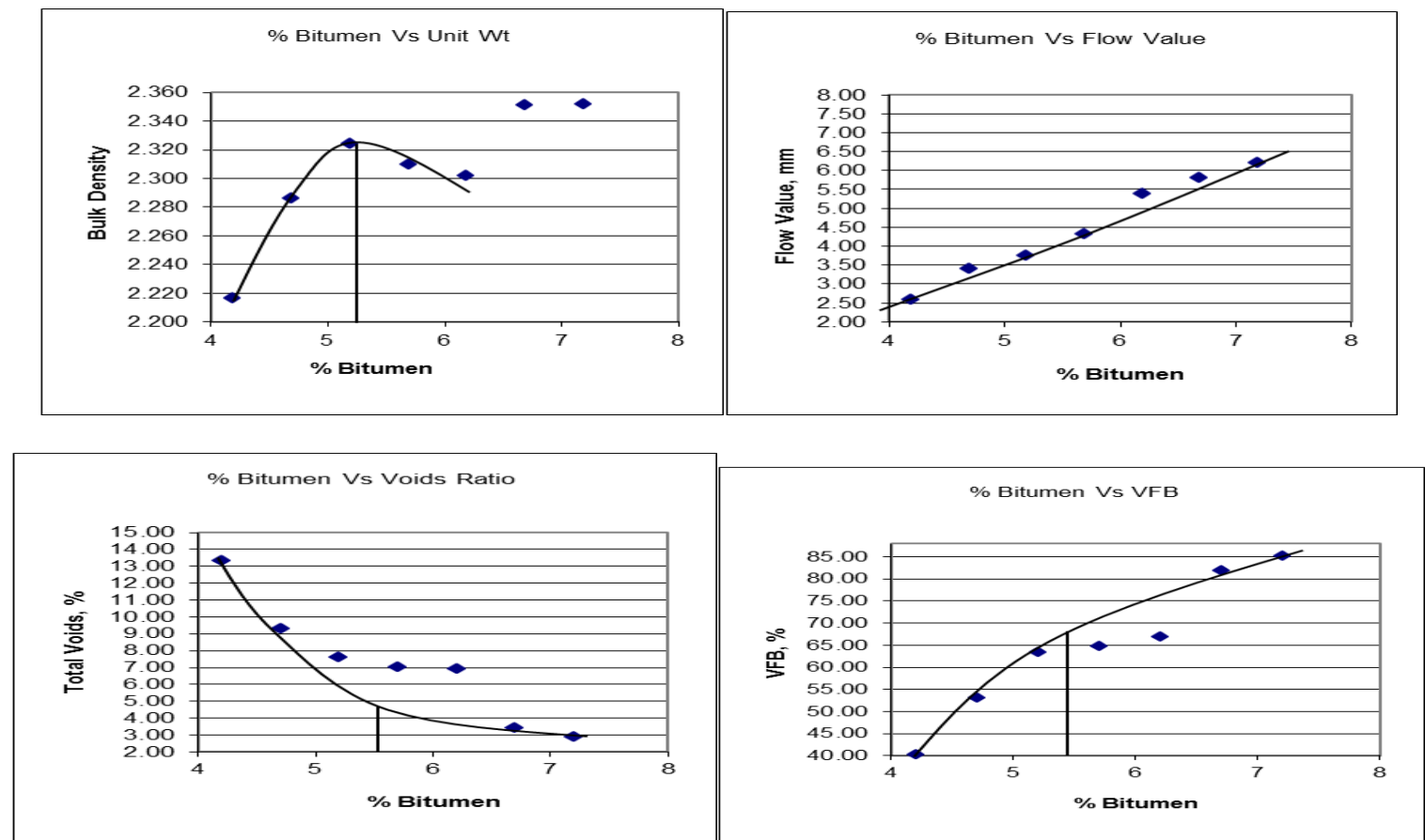

Fig 4.1: Marshall Properties of Bituminous Concrete Mix to determine OBC

4.2 Marshall properties of Bituminous concrete mix

Marshall Stability test were conducted by varying compacting temperature from $100^{\circ} \mathrm{C}$ to $160^{\circ} \mathrm{C}$ by an increment of $20^{\circ} \mathrm{C}$ using optimum bitumen content 5.2\% and test results are presented in Table 4.3 showing Marshall stability and Flow value for $80 / 100$ and PMB mix both soaked and unsoaked condition. Comparison of Marshall properties v/s Compaction temperature are tabulated in Table 4.4 and Fig 4.3

Table 4.3 Marshall Stability values and Flow values of BC mix, 80/100 and PMB: 
International Advanced Research Journal in Science, Engineering and Technology

Vol. 8, Issue 8, August 2021

DOI: $10.17148 /$ IARJSET.2021.8877

\begin{tabular}{|c|c|c|c|c|c|c|c|c|}
\hline \multirow{2}{*}{$\begin{array}{c}\text { Temperature } \\
\left({ }^{\circ} \mathbf{C}\right)\end{array}$} & \multicolumn{4}{|c|}{ Marshall stability (kg) } & \multicolumn{4}{c|}{ Flow(mm) } \\
\cline { 2 - 9 } & $\mathbf{8 0 / 1 0 0}(\mathbf{k g})$ & \multicolumn{2}{|c|}{ PMB (kg) } & \multicolumn{2}{|c|}{$\mathbf{8 0 / 1 0 0}$} & \multicolumn{2}{c|}{ PMB } \\
\cline { 2 - 9 } & Unsoaked & soaked & Unsoaked & soaked & Unsoaked & soaked & Unsoaked & soaked \\
\hline 100 & 624 & 444 & 686 & 495 & 4.3 & 7.5 & 3.0 & 5.0 \\
\hline 120 & 768 & 564 & 878 & 664 & 4.0 & 7.3 & 2.6 & 4.5 \\
\hline 140 & 1032 & 768 & 1136 & 878 & 3.5 & 7.0 & 2.3 & 3.8 \\
\hline 160 & 1200 & 900 & 1418 & 1114 & 3.3 & 6.5 & 2.0 & 3.5 \\
\hline
\end{tabular}
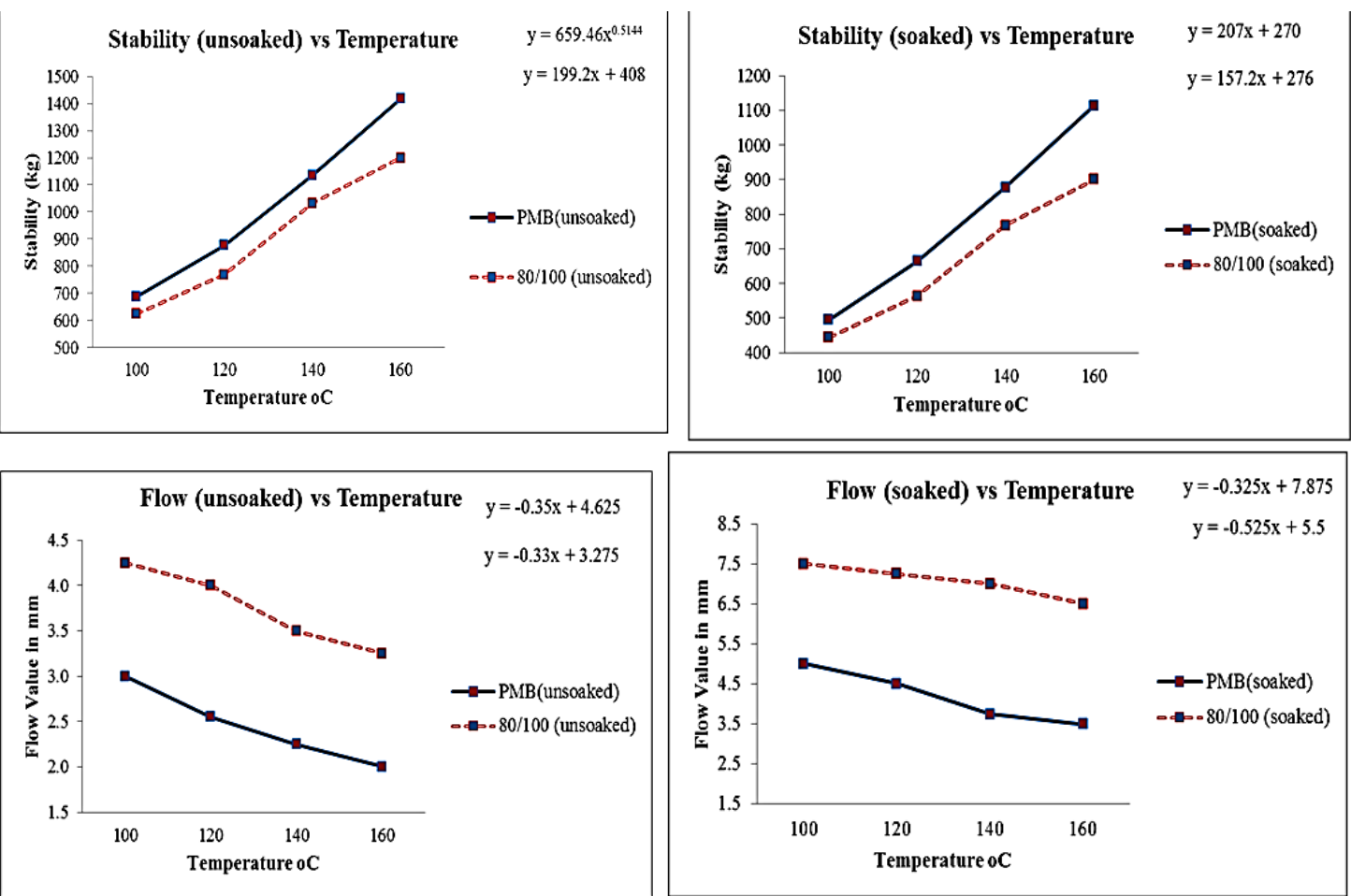

Fig 4.2 : Comparison of Marshall Stability \& Flow Parameters v/s Compaction Temperature at 1000C,1200C,1400C and 1600C for PMB and 80/100 BC mix (soaked and unsoaked)

Table 4.4 Basic Marshall Properties Of BC Mix, 80/100 and PMB:

\begin{tabular}{|c|c|c|c|c|c|c|c|c|c|c|c|c|}
\hline \multirow{2}{*}{$\underset{{ }^{\text {Temp }}}{\text { Temp }}$} & \multicolumn{2}{|c|}{$\mathrm{Vv}(\%)$} & \multicolumn{2}{|c|}{ VFB $(\%)$} & \multicolumn{2}{|c|}{$\mathrm{Vb}(\%)$} & \multicolumn{2}{|c|}{ Gm (g/cc) } & \multicolumn{2}{|c|}{ VMA (\%) } & \multicolumn{2}{|c|}{ Soaking Index } \\
\hline & $80 / 100$ & PMB & $80 / 100$ & PMB & $80 / 100$ & PMB & $80 / 100$ & PMB & $80 / 100$ & PMB & $80 / 100$ & PMB \\
\hline 100 & 7.67 & 6.23 & 60.65 & 65.78 & 11.81 & 11.97 & 2.32 & 2.35 & 19.47 & 18.19 & 0.71 & 0.72 \\
\hline 120 & 6.77 & 5.44 & 63.76 & 68.94 & 11.91 & 12.06 & 2.34 & 2.36 & 18.67 & 17.49 & 0.73 & 0.76 \\
\hline 140 & 6.32 & 4.72 & 65.42 & 72.03 & 11.96 & 12.14 & 2.35 & 2.38 & 18.28 & 16.85 & 0.74 & 0.77 \\
\hline 160 & 5.79 & 4.03 & 67.47 & 75.18 & 12.02 & 12.22 & 2.36 & 2.40 & 17.81 & 16.25 & 0.75 & 0.79 \\
\hline
\end{tabular}


DOI: $10.17148 /$ IARJSET.2021.8877
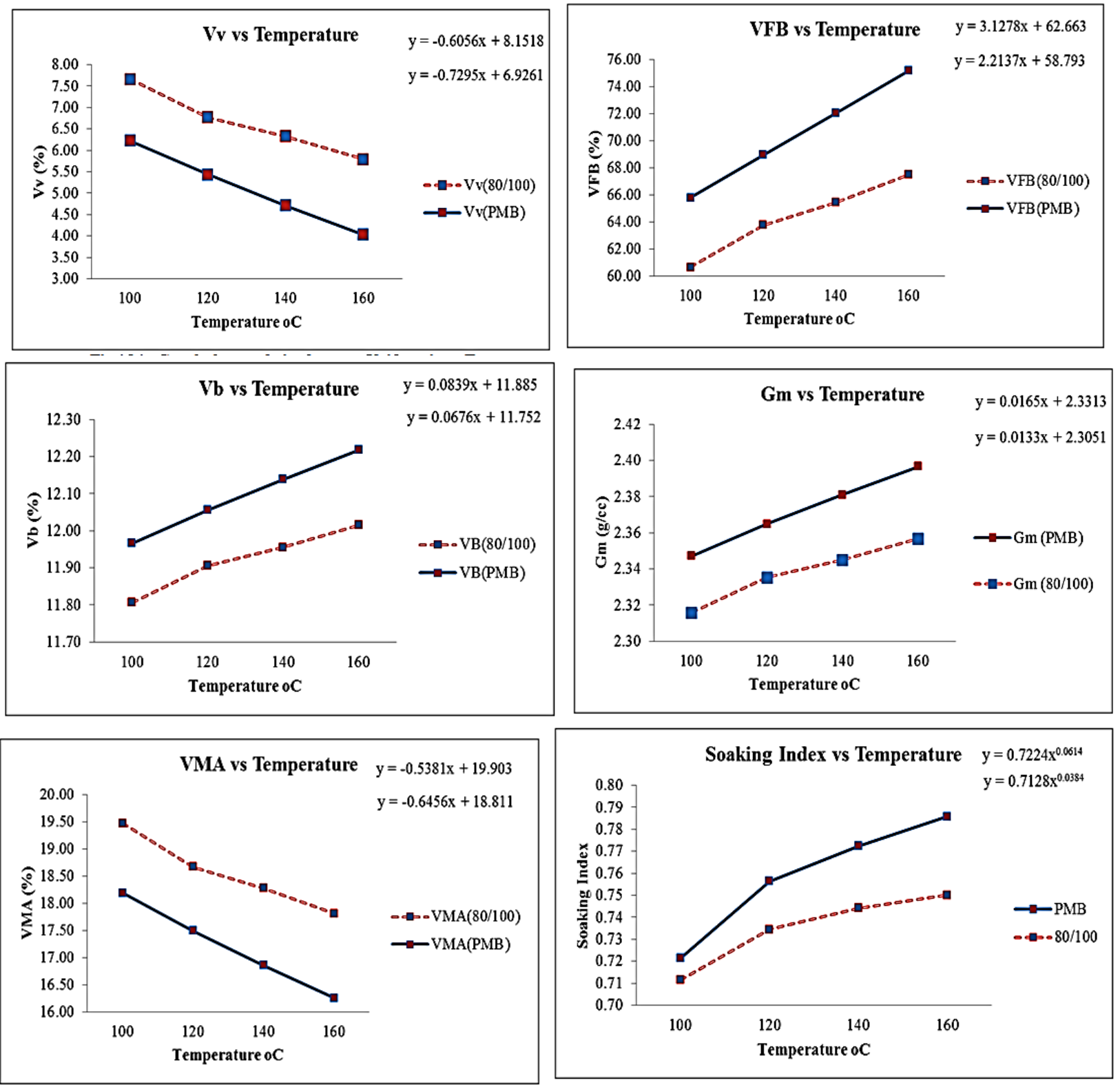

Fig 4.3 : Comparison of Marshall properties v/s different Compaction Temperature for PMB and 80/100 BC mix

\subsection{General}

\section{DISCUSSIONS AND CONCLUSIONS}

The results analysed from the laboratory investigations on $80 / 100$ and $\mathrm{PMB}$ binders at different temperature $100^{\circ} \mathrm{C}$ to $160^{\circ} \mathrm{C}$ are discussed with respect to their mix properties and susceptibility for stripping through soaking conditions as below.

5.2 Effect of Compaction temperature on various Marshall Properties.

\begin{tabular}{|c|c|c|}
\hline $\begin{array}{l}\text { Marshall } \\
\text { Property }\end{array}$ & $\begin{array}{c}\text { Change in property w.r.t } \\
\text { increase in temp }\end{array}$ & Remarks \\
\hline Voids ratio(\%) & $\begin{array}{l}\text { a. decreases linearly from } \\
7.67 \text { to } 5.79-80 / 100 \text { mix } \\
\text { b. decreases linearly from } \\
6.23 \text { to } 4.03 \text { - PMB mix }\end{array}$ & $\begin{array}{l}\text { This decrease is due to lubricating effect of } \mathrm{BC} \text { keeping } \\
\text { viscosity of the binder suitable for compaction. }\end{array}$ \\
\hline $\begin{array}{l}\text { Voids Filled } \\
\text { Bitumen } \\
(\%)\end{array}$ & $\begin{array}{l}\text { a. } \quad \text { increases linearly from } \\
60.65 \text { to } 67.47-80 / 100 \text { mix } \\
\text { b. increases linearly from } \\
65.78 \text { to } 75.18 \text { - PMB mix }\end{array}$ & $\begin{array}{l}\text { This increase is due to lubricating effect of binder, which } \\
\text { increase the workability of the mix and improves the } \\
\text { compaction. }\end{array}$ \\
\hline
\end{tabular}




\section{International Advanced Research Journal in Science, Engineering and Technology}

Vol. 8, Issue 8, August 2021

DOI: 10.17148/IARJSET.2021.8877

\begin{tabular}{|c|c|c|}
\hline Bulk Density & $\begin{array}{l}\text { a. increases linearly from } \\
2.32 \text { to } 2.36-80 / 100 \text { mix } \\
\text { b. } \quad \text { increases linearly from } \\
2.35 \text { to } 2.40 \text { - PMB mix }\end{array}$ & $\begin{array}{l}\text { This is because temperature decreases viscosity and made } \\
\text { compaction easy. }\end{array}$ \\
\hline $\begin{array}{l}\text { Marshall Flow } \\
(\mathrm{mm})\end{array}$ & $\begin{array}{l}\text { a. decreases linearly from } \\
4.3 \text { to } 3.3-80 / 100 \text { mix } \\
\text { b. decreases linearly from } \\
3.0 \text { to } 2.0 \text { - PMB mix }\end{array}$ & $\begin{array}{l}\text { a. The flow required as per MoRTH i.e. } 2-4 \text { is } \\
\text { achieved in the range of temperature } 120^{\circ} \mathrm{C} \text { to } 140^{\circ} \mathrm{C} \text { for } \\
80 / 100 \text { mix } \\
\text { b. The flow required as per IRC-SP-53-2002 i.e. } \\
2.5-4 \text { is achieved in the range of temperature } 140^{\circ} \mathrm{C} \text { to } \\
160^{\circ} \mathrm{C} \text { for PMB mix }\end{array}$ \\
\hline $\begin{array}{l}\text { Marshall } \\
\text { Stability(kg) } \\
\text { (unsoaked) }\end{array}$ & $\begin{array}{l}\text { a. increases linearly from } \\
624 \text { to } 1200-80 / 100 \text { mix } \\
\text { b. increases linearly from } \\
686 \text { to } 1418 \text { - PMB mix }\end{array}$ & $\begin{array}{l}\text { a. The stability required as per MoRTH i.e. } 900 \mathrm{~kg} \\
\text { is achieved at the temperature } 130^{\circ} \mathrm{C} \text { for } 80 / 100 \mathrm{mix} \\
\text { b. The stability required as per IRC-SP-53-2002 i.e. } \\
1000 \mathrm{~kg} \text { is achieved at the temperature } 131.46^{\circ} \mathrm{C} \text { for PMB } \\
\text { mix }\end{array}$ \\
\hline $\begin{array}{l}\text { Marshall } \\
\text { Stability(kg) } \\
\text { (soaked) }\end{array}$ & $\begin{array}{l}\text { a. increases linearly from } \\
444 \text { to } 900-80 / 100 \text { mix } \\
\text { b. } \quad \text { increases linearly from } \\
495 \text { to } 1114 \text { - PMB mix }\end{array}$ & $\begin{array}{l}\text { This increase is due to the more adhesive forces caused by } \\
\text { the decrease in the viscosity of the BC to reach the good } \\
\text { workable and compaction condition }\end{array}$ \\
\hline
\end{tabular}

\subsection{CONCLUSIONS}

1. Bituminous concrete mix grade-II considered for the study is greatly influenced by compacting temperature w.r.t mix properties like Vv, VFB, Flow, Stability, and Bulk Density.

2. Marshall Stability increases with increase in compacting temperature. Marshall stability required as per MoRTH for $\mathrm{BC}$ mix is found to be achieved at temperature range of $120^{\circ} \mathrm{C}$ to $140^{\circ} \mathrm{C}$ for $80 / 100$ grade and range of $130^{\circ} \mathrm{C}$ to $150^{\circ} \mathrm{C}$ for PMB grade as per IRC-SP-53-2002.

3. Marshall Flow decreases with the increase of compaction temperature because it increases the bitumen coating of the aggregate, and the filling of pores with binder.

4. Soaking Index which represents the tendency of the mix to stripping, increases with the increase in temperature which is a natural phenomenon where the temperature acts as catalyst whereas the soaking index changes less in PMB compared to 80/100 bitumen.

\section{REFERENCES}

1. Ministry for Road Transportation and Highways (MORT\&H), "Specifications for Road and Bridge Works (Section 504)", Fourth Revision. 2. Indian Roads Congress, "Guidelines on Use of Polymer and Rubber Modified Bitumen in Road Construction", IRC: SP-53- 2002. Indian Roads Congress, New Delhi.

3. Khanna and C.E.G. Justo, "Highway engineering”, Nem Chand \& Bros, Roorkee, Eighth Edition, 2001.

4. "Effects of Moisture, Compaction Temperature and Gradation Types on Durability of Asphalt Concrete Mixtures" by Imad Al-Shalout , Rateb Stas and Osama Miro4, Damascus Univ. Journal Vol. (23)-No. (2)2007

5. Asphalt Institute Technical Advisory Committee Guidance, Document Determination of Laboratory Mixing and Compaction Temperatures for Hot-Mix Asphalt, August 2011

6. IRC: 29-1978, "Specifications for Bituminous Concrete (Asphalt Concrete) for Road Pavement (First Revision)" - IRC, 1978.

7. L. Michael H. Hunerand E.R. Brown, "Effects of Re-heating and compaction temperature on hot mix asphalt volumetric", NCAT Auburn University, November-2001.

8. Dr.H.C.Mehndiratta \& Praveen kumar, "Effect of Mixing and Compacting temperatures on marshall parameters of bituminous mixes".

9. Larry AK Silas Tirau, "Evaluation of Hot Mix Asphalt (HMA) properties compacted at various temperatures", project report, November-

2005.

10. $\quad$ Asphalt Institute (1990). “Laboratory Mixing and Compaction Temperature.” Lexington, Kentucky, United States of America: Asphalt Institute, Research Park Drive.

11. Stuart, Kevin. D., (2002), Methodology of Determining Compaction Temperature for Modified Asphalt Binder, Federal Highway Administration, U.S Department of Transportation, Virginia.

12. Noorafidah Binti Ithnin "Determination of Mixing and Compacting Temperatures for Hot Mix Asphalt".

13. "Determination of mixing and compacting temperatures for hot mix asphalt" by Noorafidah Binti Ithnin, universiti Teknologi Malaysia.

14. Standard Specification for Transportation Materials and Methods of sampling and testing. fifteenth Edition 1990, Part II Tests, Adopted by the American Association of state Highway and Transpiration officials.

15. "Effect of mixing and compaction temperatures on the indirect tensile strength and fatigue behaviour of bituminous concrete mix prepared using polymer modified bitumen" by Sharanabasappa Kori 